\title{
Global Security in the 21st Century
}

\author{
M. H. Saier Jr. • J. T. Trevors
}

Received: 8 June 2007 / Accepted: 17 September 2007 /Published online: 11 January 2008

(C) Springer Science + Business Media B.V. 2007

Security is a central human concern that includes numerous sub-listings. We often think of economic security, national security, energy security, nuclear security, cyber security, democratic and civil rights security, personal security and health care security as some examples. However, what is becoming very clear is that we should all be concerned with global security of our common, shared biosphere. Global security encompasses all of the above, but even more importantly, it depends on our environmental/ecological security. It also requires the establishment of universal human rights and civil liberties. The achievement of global security will require a complex, interconnected network of humans and their activities in a rapidly changing world. The focus must be on global climate change and human population growth, which are rapidly emerging as the two most important threats.

The threat of nuclear weapons is still with us, but its relative importance may decline as global climate change and human population growth continue to degrade our biosphere. We must also focus on the

\footnotetext{
M. H. Saier Jr. ( $\square)$

Biological Sciences, University of California at San Diego, La Jolla, CA 92093-0116, USA

e-mail: msaier@ucsd.edu

J. T. Trevors

Department of Environmental Biology,

University of Guelph,

Guelph, ON N1G 2W1, Canada

e-mail: jtrevors@uoguelph.ca
}

many types of pollution that contribute to ecosystem instability and species extinction.

Wars contribute immensely to societal instability and environmental degradation. Wars represent a form of carelessness which we no longer can afford. Nuclear weapons should be disassembled and wars halted. Military disciplines must be regulated by an international force, and expenditure of large sums of money for military must be prevented. Such uses of our resources are archaic and obsolete. We have more important problems to face and conquer.

To complicate the situation, we also need to consider existing and emerging infectious diseases. There is a paucity of global infrastructure that is required to combat them. No one will feel secure when global epidemics hit. Natural selection of humans via infectious diseases will be cruel with immense suffering and death.

The situation is grave, but there are actions that can be taken that will ameliorate our plight. We need responsible governmental officials who respect and obey international law. They must recognize that the needs of the world community must supercede national interests. Those who refuse must be expelled from office. Impeachment followed by severe punishment must become a standard consequence of dishonesty, corruption and activities based on selfinterest rather than the public interest. If billions of dollars had not been spent on military, just think what we could have accomplished. Universal human rights, birth control, healthcare and education could have been guaranteed for the same cost. Only if dealt with 
at the global level can we effectively counteract the consequences of climate change. This will require moving cities inland, managing an immense refugee population, relocating agriculture, and implementing conservation measures to prevent species extinction. Humans will need to have energy and food security as well as cyber security if conservation efforts in our declining world are to succeed.

Worldwide terrorism is another threat to global security. Caused in part by greed and incompetent leadership, terrorism can be a direct consequence of overpopulation, limited resource availability and the resultant poverty and personal frustration. Terrorists often flourish where conditions cause the young to outnumber the older, more staid members of society, and where opportunity is restricted. It can be a transnational activity without borders, as is the case today in many Arab nations. This is one reason why terrorism is so widespread in our current world, and why this threat is continuously growing. No single country can be held responsible, but some are more responsible than others. The U.S., for example, was defying UN dictates and international law by initiating wars on the basis of lies. U.S. policy, by taking a lawless course, encouraged and continues to encourage lawlessness by others. It is promoting a world wide web of terror. Recent reports have come to exactly this conclusion although the causes have been attributed to different factors, depending on the political bias of specific individuals.

Environmental/ecological security can be improved by using scientific knowledge and experimentation to shape public policy. This is pressing because of the increasing rate of global climate change. The opportunity to act may be short lived. Current droughts, extreme weather fluctuations, floods and elevated temperatures all indicate that the time period to prevent disaster may have already passed. Imbalances in public health and economic provisions must be corrected. Reduced energy usage coupled to increased energy efficiency and the development of alternative energy sources will help alleviate the current imbalance.

Given that over three billion people currently reside in states that cannot provide the basis necessities of life, no one should be surprised by the rise of terrorism. Responsible democratic governments must slowly be established, not forcibly, but voluntarily. The magnitude of the problem becomes obvious when the root problem of overpopulation is considered. International aid and cooperation will prove to be essential if we are to avoid the obvious consequences of overpopulation. An increased role of the United Nations and other international organizations would be highly desired. We must put time, money and effort into these pursuits or security will never be achieved. 